\title{
A study of the United States of America and China's new cold war conflicts and the flexible survival strategy for Korean security*
}

\author{
Haesoo Yang**
}

\begin{abstract}
China is challenging the hegemony of the United States through its economic power, creating the so-called New Cold War. The consequent conflict between the US and China can cause selective coercion in South Korea. South Korea is highly dependent on the United States militarily and on China economically. In a conflict, if Korea is asked for selective support, there will be a dilemma in policymaking. Accordingly, I studied the geopolitical dilemma in South Korea resulting from the US-China competition and six security issues . I was able to identify six conflict factors related to Korean security: the North Korean nuclear problem, the role of US forces in South Korea, friction due to protectionism, the battle for the semiconductor market, the formation of the Pacific Coast Council, and the discharge of contaminated water from nuclear power plants in Japan. I examined the flexible survival strategies that Korea could choose for each security issue. I expected policy utility by dividing it into military, economic, and diplomatic fields.
\end{abstract}

Keywords : U.S.-China conflict, new Cold War, protectionism, survival strategy, Pacific Council

* This research was supported by Seokyeong University in 2021.

** (First Author) Seokyeong University, Department of Military Studies, Professor, didgotn@hanmail.net, https://orcid.org/0000-0003-4626-0302 


\section{I. 서론}

1991년 소련의 붕괴로 사실상 미국과 소련의 냉전은 종결되었다. 미국이 세계의 유일한 패권 국 가로 우뚝 선 것이다. 미국의 패권은 당분간 지속될 것으로 예측되었으나 이에 도전하는 국가가 또 다시 등장했다. 이는 다름 아닌 중국으로 한때 아시아의 최강자로 군림하던 국가이다. 중국은 덩샤 오핑의 흑묘백묘 논리에 의한 일부 시장경제를 도입하여 노선의 변화를 시도했다. 나아가 경제특구 선정과 기업개혁을 통해 경제구조를 개선하는 데 성공했다. 이어 시진핑은 경제력을 바탕으로 미국 을 추격하기 위해 박차를 가하고 있다. 미국은 이러한 중국의 고속 성장을 탐탁하게 생각하지 않는 다. 무엇보다 자유 진영의 맹주인 미국은 공산주의 국가인 중국과 이념이 다르기 때문이다. 이뿐만 아니라 중국의 코로나 책임론, 중국의 홍콩 보안법 제정, 타이완의 일국양제(一國兩制) 거부, 미국 증시에 상장한 중국 기업 제재 등 다양한 요인들이 뒤섞여 대립하고 있다. 이른바 신냉전이다. 미국 과 중국의 갈등은 양국 자체에서 종결되지 않고 한국에 직 - 간접적인 영향을 미칠 수밖에 없다. 미 국 입장에서 한국은 중국을 압박하기 유리한 위치이며, 실제 주한미군을 통해 중국을 효과적으로 견제하고 있다. 나아가 미국은 “중국 문제에 대응하는데 동맹국과 긴밀히 연대하겠다”라며 여기에 한국도 거론했다.1) 중국 입장에서도 한반도가 순망치한(脣亡齒寒)의 논리에 입각하여 중요성이 높 다. 2016년에는 주한미군용 사드 배치를 둘러싸고 중국이 한국을 향해 경제보복을 가하자, 미 - 중 갈등은 한·중 갈등을 넘어서 한 - 미 갈등으로 확대되었다.

미 · 중의 패권전쟁이 현실로 다가옴에 따라 지정학적으로 밀접한 상관관계에 있는 한국에 직 • 간접적으로 영향을 미치고 있다. 한국은 미국과 중국의 신냉전이 도래한 상황에서 두 강대국가와의 지혜로운 관계 설정이 필요하며, 이를 위해 안보 분야에 대한 유연한 생존전략을 고민하지 않을 수 없게 되었다. 따라서 본 논문의 연구목적은 미· 중 경쟁으로 인해 파생되는 한국의 지정학적 딜레 마와 그로 인한 안보 현안을 분석하는 것이고, 이때 한국은 어떻게 생존할 것인가에 대한 의문이 제기되어 연구를 시작했다. 미·중 신냉전에 관한 연구는 활발하게 진행되어왔다. Kim, H. K. (2014)는 세력전이이론에 입각하여 미 · 중 국력의 차이를 분석하였다. 그러나 패권 관점에서 갈등 요인에 관한 논의가 없어 추가적인 분석이 필요하다. Lee, S. U. (2019)는 미 • 중의 패권전쟁 양상 과 홍콩과의 연계성을 고찰하였다. 하지만 양국관계가 한국에 미치는 영향은 추가적인 연구가 필요 하다. Lee, S. H. (2020)은 미 • 중 갈등의 범위가 코로나19까지 전방위적으로 확대되는 것을 우려하 였다. 이를 통해 사회문제를 위협의 대상으로 포함하고 있으나, 신냉전과의 상관관계에 관한 연구 의 한계성을 보인다. 나아가 정한범 등(2020, pp. 51-210)2)는 미 • 중의 동아시아 전략에 대한 한국 의 대비책을 도출하였고, Kim, H. K. (2018, pp. 213-241)은 미·중의 상호정책 변화에 대해 한국이

1) 세계일보(2020.5.22.). http://www.segye.com/newsView/20200522516953

2) 정한범, 정구연, 유상범, 정재흥, 양정학, 방준영, 조은일, 김선래, 김규철, 최경희 (2020). (2020) 동아시아 전략평가. 서울: 동아시아안보전략연구회. 
선택해야 할 방향을 제시하였다. 이 연구는 미 · 중 개별국가의 정책에 대해 한국의 대응 방법에 관 한 논의로, 양국 정책의 대립에서 파생되는 갈등 구조를 분석하기에 한계가 있다.

정리하면, 미·중의 신냉전과 관련된 대부분의 연구는 신냉전의 도래를 우려하거나, 신냉전에 따른 한국의 대응 전략을 중점적으로 연구하고 있다. 결국, 기존 연구로는 신냉전으로 인한 양국의 갈등을 한국 입장에서 분석하고, 그 패러다임 속에서 맞춤식 해법을 설명하기에 한계가 있다. 이때 제기된 대응 전략은 한국이 주도적으로 적용하기 제한되며, 가시적인 대응 결과와 이에 상당한 대 응 효과를 도출하는데 난제가 있었다. 따라서 한국은 미· 중의 대립이 확대될 경우를 대비하여 두 강대국가와의 지혜로운 관계 설정이 필요하며, 이를 위해 본 연구에서는 미·중 경쟁으로부터 파 생되는 한국의 안보 현안을 분석하여 유연한 생존전략을 정립할 것이다. 안보에 대한 분석요인은 연구 중점에 따라 다양하다. 김열수(2019, p. 9)3)는 위기관리 측면에서 안보의 분석수준을 정치 경제 - 사회 · 군사 - 환경 - 과학기술안보로 분류하였다. 황진환 등(2014, pp. 18-27)4)은 각종 사회 문제를 설명하기 위해 정치 - 경제 - 군사 - 환경안보로 구분하였다. 본 연구에서 안보에 대한 분석 요인은 국제관계 측면에서 일반적으로 통용되는 사전적 의미5)를 반영하여 군사, 경제, 외교로 선정 하였다.

\section{ㅍ. 신냉전에 대한 이론적 고찰}

\section{1 냉전의 이해}

역사적으로 어떤 강대국도 영원토록 패권을 유지하지 못했다. 모든 길이 로마로 통한다며 세계 를 호령하던 로마제국은 멸망하고 없다. 식민지 점령으로 해가 지지 않던 대영제국 마찬가지 미국 에게 패권을 넘겨주었다. 미국은 제 2 차 세계대전이 종료되면서 패권을 독식할 것 같았지만 소련의 도전을 받아 냉전을 겪었다. '냉전(The Cold War, 冷戰)'이란 제2차 세계대전 종전 이후 미국과 소 련을 중심으로 양분된 자유 진영과 공산 진영의 국제정치적 대립 관계를 말한다. 적대 상태의 두 국가가 무기를 통해 직접적인 군사력을 투사하는 것을 열전이라 한다면, 냉전은 무력을 사용하지 않고 경제나 외교 등의 수단으로 대립하는 국제관계이다. 이 용어는 1947년 미국 대통령 고문이었 던 버나드 바루크(Bernard Baruch)가 의회 토론에서 처음 사용했다. 학문적으로 미국 저널리스트 리프먼(Walter Lippmann)이 연구한 논문 『The Cold War』(1947)에서 비롯되었다.6) 정상모(2002,

3) 김열수(2019). 국가안보-위협과 취약성의 딜레마. 경기: 법문사.

4) 황진환, 서춘식, 윤정원, 김순수, 김인수, 정성임(2014). ㅎ⽄국가안보론. 서울: 박영사.

5) (검색일: 2021.5.14.) https://dic.daum.net/word/view.do?wordid=kkw000168942\&q=\%EC\%95\%88\%EB\%B3\%B4\&suptype= KOREA_KK.

6) 이희승 편저(2013, p. 703). 국어대사전. 경기: 민중서림. 
pp. 78-80)7)는 냉전의 원인이 제2차 세계대전 종전 직전 자본주의와 사회주의의 긴장 관계에서 태 동한 것으로 분석했다. 1942년 5월 29일 미국 루스벨트 대통령은 전후 세계질서 유지를 위해 미 영 - 중 - 소에 의한 '4대국 경찰관' 구상을 몰로토프 소련 외상에게 밝혔다. 중국을 강대국 대열에 합류시킨 배경에는 소련을 견제하려는 속내가 담겨있었다. 이때 유럽 열강 대부분은 전쟁 후유증으 로 유럽의 세계질서 주도권을 상실했다. 이에 따라 미국과 소련이 서로의 이익을 다투는 양극화 현 상을 초래했다.

냉전은 40 여 년간 국제관계에서 주요 갈등 요인이었다. 하지만 국제질서가 동서 진영의 대립에 서 벗어나 다극화 양상을 보이면서 1989년 11월 9일 독일의 베를린 장벽이 붕괴했다. 이어 1990년 9월 12 일 제 2 차 세계대전 전승국인 미국 - 소련 - 영국 - 프랑스는 이른바 '대(對)독일 화해조약'을 조인했다. 국제사회가 통일을 인정하면서 1990년 10월 3일 독일은 공식적으로 통일되었고, 이로써 자유 진영과 공산 진영의 냉전체제는 사실상 막을 내렸다. 1990년 독일의 통일과 1991년 소련의 해 체를 냉전의 종말로 여길 것인가 여부는 이견이 존재한다. 사회주의권 붕괴로 국제질서가 평화 공 존기로 접어든 것은 분명하나, 냉전 구도가 존재하는 현실에서 냉전의 종말을 고하기는 시기상조라 는 일부 주장도 있다. 예컨대, Kim, B. J. (2018, pp. 272-273)은 미국이 힘의 외교에서 거둔 냉전의 종식은 인권문제에서 한계를 보인다고 주장하여 이를 뒷받침한다.

\section{2 미·중 신냉전의 도래}

\section{2 .1 세계 패권의 전이}

소련이 붕괴한 지 30년이 지난 현시점에서 미국은 패권을 위협하는 또 하나의 국가와 대립하고 있다. 이는 1990년대 이후 고속 성장을 이룩한 중국이다. 중국은 2008년 글로벌 금융위기를 계기로 세계무대에서 양극 체제의 기반을 다졌다. 통계청(2021)8)에 따르면, 중국의 GDP는 1990년 이전까 지 한국보다 낮았다. 하지만 개혁 - 개방정책의 성과에 힘입어 2020년 약 14 조 달러로 성장하였고, 미국 $\mathrm{GDP}$ (약 21조 달러) 못지않은 경제 대국이 되었다. 중국의 막강한 경제력은 미국 중심의 패권 질서에 도전할 단초가 되었다. 이뿐 아니라 외교적인 측면에서 유엔 안보리의 상임이사국으로서 주 변국에 미국과 대등한 영향력을 행사하고 있다. 미· 중이 최강자의 지위를 놓고 자웅을 겨룰 여건 이 형성된 것이다.

오간스키(Organski, 1968, pp. 338-376)와 이상우(2013, pp. 232-250)9)는 힘이 항상 이동하므로 장기간에 걸쳐 국력의 변화를 확인해야 한다고 세력전이이론을 주장했다. 이때 국가는 지배자의 위 치에 오르려는 욕망을 가지게 되며, 패권을 가진 자와 도전하는 자 사이에 마찰이 생긴다는 것이다.

7) 정상모(2002). 신냉전 구도와 평화: 누가 신냉전과 한반도 전쟁을 부추기는가!. 서울: 월간말.

8) 통계청. G20 국가의 주요지표. KOSIS 국가통계포털. http://kosis.kr/(검색일: 2021.4.15).

9) 이상우(2013). 국제관계이론. 서울: 박영사. 
따라서 현재 질서를 유지할 평화의 조건은 지배국의 국력이 도전국의 국력을 압도할 때 가능하다 는 것이 오간스키의 분석이다. 이때 지배국과 도전국의 국력이 비슷할 경우 전쟁 가능성이 있다고 우려하여, 세력전이이론은 신냉전이 출현할 당위성을 설명하고 있다.

미국 전 하원의장 뉴트 깅리치(Gingrich, 2019, pp. 17-24)는 미국이 건국 이후 네 차례의 큰 도전 속에 역사를 발전시켰다고 분석했다. 그것은 첫째, 영국과 치른 독립전쟁, 둘째는 노예해방을 위한 남북전쟁, 셋째는 파시즘에 맞선 제 2 차 세계대전, 넷째는 공산주의와 대항한 소련과의 냉전을 말한다. 나아가 그는 패권적 민족주의에 맞서 중국공산당과의 전쟁을 다섯 번째 응전으로 예견했다. 미·중 의 패권전쟁이 현실로 다가올 수 있다는 사실을 경고한 것이다. 미국 바이든 대통령과 중국 시진핑 국가주석의 미 • 중 화상 정상회담이 2021년 11월 16일 진행되었다. 바이든 대통령 취임 후 미·중 의 첫 정상회담이라는 성과에도 불구하고, 갈등 요인들에 대해 설전으로 일관하여 오히려 관계가 악화되었다는 우려를 낳았다. 일부 전문가들은 본 회담을 냉전 시대의 미·소 정상회담과 유사한 양상이라 분석하면서 미 · 중 갈등을 '신냉전'이라 평가하였다.10)

정리하면, 중국의 국력은 막강한 경제력을 바탕으로 미국과 어깨를 나란히 하고 있다. 국제정치 전문가에 의하면 지배국과 도전국의 국력이 비슷할 경우 패권국의 지위를 놓고 전쟁 가능성에 대 한 우려가 있다. 미국 정치지도자 뉴트 깅리치도 중국의 패권적 민족주의에 맞서 전쟁이 필연적임 을 예견하고 있다. 즉, 신냉전의 시대가 도래하였음을 기정사실로 하고 있다.

2.2 .2 신냉전에 관한 담론

신냉전이라는 용어는 1970년대 말에서 1980년대 초 역사가들 사이에서 회자 되었다. 그런데 당 시 사회는 냉전 초기와 유사하게 동서의 긴장 상태가 극심한 시기였다. 중국의 급속한 성장으로 미 국과 갈등이 심화되면서 이제 국제관계에서도 신냉전 용어가 주목받고 있다. 폼페이오 미 국무장관 은 2020년 7월 23일 닉슨 도서관 연설을 통해 미국에 대한 중국발 도전을 언급하면서 사실상 중국 과의 냉전을 선언했다. 이러한 상황에서 미·중 갈등을 미 - 소 냉전과 구분하여 신냉전이라는 용 어로 조정하여 담론화하는 기류가 형성되었다(Ban, 2021). 이러한 개념을 적용했을 때, 신냉전은 '미국과 유럽 등 서구와 러시아, 중화인민공화국 간의 냉전이 탈냉전으로 되었다가 다시 옛날의 냉 전과 같이 군사적 대립으로 치닫는 현상'을 말한다. 신냉전의 기원에 대한 논의는 지역이나 시기, 관점에 따라 다양하다. 이는 탈냉전의 종식이 언제인가라는 과제와 연계된다. 미국과 중국을 중심 으로 전개되는 신냉전의 기원은 2008년과 2016년 두 가지로 나뉜다.

중국은 2008년 글로벌 금융위기를 계기로 세계무대에서 양극 체제의 기반을 다졌고, 이를 계기 로 베이징 올림픽을 개최하였다. 이 과정에서 중국 정부가 티베트 시위를 유혈 진압하여 프랑스를 비롯한 국제사회와 대립하였다. 중국 정부의 인권탄압에 항의하여 서방의 베이징 올림픽 개막식 보

10) US White House, Readouts President Biden's Virtual Meeting with President Xi Jinping of the People's Republic of China, November 16, 2021; The New York Times International Edition, November 18, 2021. 
이콧 등 일련의 조치를 고려한다면, 신냉전의 기원은 2008년경으로 분석된다. 신냉전의 근본적인 배경은 경제적 대립으로부터 출발하였지만, 종국에는 군사적 갈등으로 확대되었다. 즉, 중국이 남 중국해에 대한 영유권을 주장하면서 이를 중심으로 영토분쟁이 제기되었다. 이어 주한미군이 한국 에 $\mathrm{THAAD}$ 를 배치하고 이로 인한 중국의 보복이 한국과 미국에 가해졌다. 이러한 관점에서 조명 한다면 신냉전은 2016년을 전후한 시기로 분석된다. 미국과 소련의 냉전은 냉전이라는 용어의 정의 에 부합되게 무력을 사용하지 않고 종결되었다. 냉전과 신냉전의 역학 구조가 유사하다면 신냉전 역시 군사력을 투사하지 않고 종료될 수 있다. 하지만 냉전과 신냉전의 구조가 근본적으로 상이하 다면 전개 양상도 달라질 것이다. 따라서 냉전과 신냉전의 공통점, 차이점에 대한 분석은 안보에 관한 국제정치 담론에서 의미가 있다.

$\operatorname{Ban}(2021$, pp. 12-34)은 신냉전이 국제관계의 구조적 변화로부터 기인하였고 주장하였다. 그는 냉전과 신냉전의 역학관계를 분석하면, 향후 신냉전의 전개 양상을 진단할 수 있다고 예견했다. 이 러한 관점을 기조로 냉전과 신냉전의 주요 공통점, 차이점을 아래와 같이 분석하였다. 신냉전은 냉 전과 유의미한 공통점을 보인다. 이는 구조적인 차원과 행위적 차원으로 살펴볼 수 있다. 첫째, 구 조적 차원에서 구조적 압력에 관한 문제이다. 냉전과 신냉전을 막론하고 초강대국이라는 행위자 사 이에서 힘의 역학관계에 변화가 발생하게 되는데 이것이 구조적 압력에 영향을 미친다. 또한, 전 세계는 두 개의 정치권으로 양분되는데, 이는 미·소 냉전과 미 · 중 신냉전에서 나타난 공통적 쏠 림현상으로 설명할 수 있다. 둘째, 행위적 측면에서의 공통점이다. 냉전이나 신냉전에서 구조적 압 력이 발생했을 때 유사한 위기관리 기능이 작동했다. 1962년 쿠바 미사일 위기에 봉착하여 미 - 소 는 위기관리 기능을 작동시켜 냉전 시대의 위기를 종결지었다. 신냉전 시대에도 미 · 중 초강대국 은 적절하게 위기를 관리하고 있다. 2020년 3월 중국은 대만 방공식별구역으로 군용기를 출동시켜 군사적 압력을 투사했다. 이에 맞서 미국은 항행의 자유 작전을 강화하여 갈등이 고조에 달했지만, 미· 중은 훈련 시간이나 장소를 적절하게 분리하여 군사적 확전을 배제하였다.

다음으로 신냉전과 냉전의 차이점이다. 이는 구조적인 압력의 방향성과 경제·안보 작동 기제 측면으로 구분하여 분석할 수 있다. 첫째, 구조적 압력의 방향성이다. 냉전과 신냉전 모두 구조적 압력이 존재하지만, 그 방향은 상이하다, 냉전은 구조적 압력이 완화하는 방향으로 진행되었으나, 신냉전은 구조적 압력이 심화하여 방향성에 차이를 보였다. 둘째, 경제·안보의 작동 기제에 관한 측면이다. 냉전 시대 소련은 자신의 관리영역을 설정하여 이른바 블록주의를 고수하였고, 영역 안 에서는 시장경제를 부정하고 계획경제를 유지했다. 미국도 마찬가지 자유민주주의 블록을 주도하 였다. 하지만 신냉전 시대에는 블록주의를 탈피하여 다자주의를 견지하고 있다. 중국은 정치적으로 공산주의를 유지하면서 경제적으로는 시장경제를 채택하여 중국 발전의 기틀로 삼고 있다. 이렇듯 미국과 중국은 다자주의 기조를 유지하고 있다. 그런데 다자주의 형태는 상호 포용에서 벗어나 배 타적으로 운영되는 특징을 보여준다.

냉전과 신냉전의 비교는 정책적 시사점을 보여준다. 두 요인은 일부 공통점이 존재하나 역학관 
계는 상이하다는 과제를 남겼다. 이러한 분석결과는 미·중 강대국 사이에 있는 한국에게 냉전 시 대 적용했던 정책을 신냉전 시대에 접목할 경우, 실패 가능성을 경고하고 있다. 즉, 신냉전이라는 유사한 용어의 함정에 빠져 동일한 처방을 내리지 않아야 한다는 함의를 포함하고 있다. 따라서 신 냉전이 한국에 미치는 영향요인에 대해 필요한 방안을 제시하기 위해 미·중의 전략 분석이 선행 되어야 한다.

\section{III. 신냉전과 미국• 중국의 전략에 따른 안보 현안 분석}

신냉전에 따른 미· 중의 대립 관계 속에서 미국의 대중전략과 중국의 대미전략을 분석하고자 한 다. 이를 통해 한국 안보에 영향을 미치는 군사, 경제, 외교적 과제를 살펴볼 것이다.

\section{1 미국과 중국의 상호전략}

미국과 중국의 패권 경쟁이 다양한 분야로 확대되면서 양국관계는 악화일로에 있다. 갈등의 지 리적 영역은 대만해협과 남중국해를 중심으로 출발하였으나, 인도-태평양을 넘어 우주와 사이버 공간으로 확대되었다. 갈등의 대상은 중국의 불공정무역, 기술탈취, 각국 국내 정치 개입 등의 행태 와 신장-위구르 인권, 대만 문제 등 실로 전방위적이다. 트럼프 미국 대통령이 코로나 19의 책임과 관련하여 중국 바이러스라는 의미의 '쿵 플루(Kung Flu)'라고 지칭한 사례도 등장했다.

미국의 중국 압박은 트럼프의 정치적 성향 때문에 심화된 것처럼 보일 수 있다. 하지만 미국의 중국에 대한 적극적 견제는 오바마 대통령 시절부터 발견된다. 2011년 힐러리 국무장관이 발표한 ‘아시아로의 회귀' 정책이 바로 그것이다. 이는 미국이 테러와의 전쟁으로 중동에 집중했던 국가이 익의 관심 분야를 아시아로 전환하겠다는 이른바 중국 포위전략이다. 이러한 관점에서 바이든 대통 령의 동맹국 우선주의도 맥을 같이 한다. 즉, 미국의 중국에 대한 견제는 특정 대통령이나 정부의 성향이라기보다 국가적 차원의 전략으로 평가된다.

미국의 압박에 중국의 입장은 단호하다. 2013년 시진핑 중국 주석은 미국 오바마 대통령에게 “태 평양은 두 대국을 수용할 만큼 넓다”라며 중국의 부상을 알렸다. 하지만 현재의 국제질서는 제 2 차 세계대전 이후 미국이 만들었는데 쉽사리 장벽을 허물기 어려울 것이다. 중국은 국제정세가 불리해 진 환경에서 국제전략을 조정해야 할 상황인데, 미국에 바이든 정부가 들어서자 트럼프 정부에게 당한 보복을 시정해 주도록 요구했다. 중국 외교부장 왕이는 '란팅포럼'에서 미 · 중 관계를 정상궤 도로 되돌리는 것을 추진한다며 대화 재개를 갈구했다. 정리하면, 중국의 대미전략은 어려운 국제 환경에서 다소 조정을 시도하겠지만 결정적 국가이익은 양보하지 않을 것이라 예견된다. 


\section{2 미국의 대중전략}

중국경제금융연구소장 전병서(2018)11)는 세계 패권국 미국이 그 지위에 도전하는 국가를 다루는 규칙이 있다고 주장했다. 미국은 도전국의 GDP가 미국의 $40 \%$ 를 넘어서면 무역 - 금융 - 자원전쟁 으로 반드시 제재를 가했다는 것이다. 그 사례로 소련과 일본이 곤경에 빠졌고, 이제 중국이 대상이 라고 들었다. 그의 주장에 따르면, 미국은 냉전 시대 소련의 $\mathrm{GDP}$ 가 미국의 $40 \%$ 를 넘어서자, 군비 경쟁과 유가 하락으로 소련의 경제를 와해하기 시작했다. 일본 마찬가지 1985 년 미국 GDP의 $45 \%$ 를 넘어설 즈음, 일본을 환율 조작국으로 지정하여 엔화를 10년 동안 $69 \%$ 절상시켰다. 결국, 일본 은 30년 장기불황의 늪에 빠져 2017년 GDP가 미국의 $25 \%$ 수준으로 하락했다. 오바마 1 기 정부 2 년 차인 2010년 중국의 $\mathrm{GDP}$ 가 미국의 $41 \%$ 에 달했으나, 글로벌 금융위기 때문에 미국은 중국에 대 해 제재를 가하지 못했다. 트럼프 집권 2년 차인 2018년, 중국의 GDP가 미국의 $69 \%$ 를 넘어서자 도전국 중국에 대한 응징이 본격화되었다.

구체적인 미국의 대중전략은 군사- 경제 - 외교 분야로 세분화하여 살펴보았다.

첫째, 군사 분야이다. 2019년 6월 미국 국방부는 2011년 오바마 정부의 '아시아 회귀(Pivot to Asia) 전략'을 '인도-태평양 전략'으로 전환하였다. 이와 동시에 중국을 수정주의 세력으로, 북한을 불량국가로 분류하였다. 이를 통해 미국은 핵심 전략이 다차원적인 대비태세와 동맹들과의 파트너 십임을 분명히 했다. 2021년 9월 1일 바이든 대통령은 아프가니스탄 미군 철수에 따른 성명을 발표 하였다. 이는 소위『바이든 독트린(Biden Doctrine)』으로, 향후 미국의 군사전략 기조가 담겨있다. 여기에서 미국은 중국과 심각한 전략경쟁을 치르고 있으며, 러시아로부터 다중 위협에 직면하고 있 어 향후 러시아와 중국에 대해 적극적 대응을 천명하였다. 하지만 구체적인 바이든 정부의 군사전 략은 미국 국가 안보전략서와 국방전략서에서 가시화될 것으로 전망된다.

둘째, 경제 분야이다. 트럼프는 '미국 우선주의'12)를 기초로 보호무역정책을 추진했다. 2018년 9 월 기준으로 중국산 제품 500 억 달러에 대해 $25 \%, 2,000$ 억 달러 물량에 대해 $10 \%$ 의 고율 관세를 부과했다. 나아가 2019년 8월 중국을 환율 조작국으로 지정하였다. 이러한 경제제재는 미국의 무역 적자 원인이 중국의 화폐가치 평가절하 때문이라는 판단하에 중국의 추격을 따돌리기 위한 전략으 로 분석된다. 2020년 8월 17일 트럼프 정부는 중국 화웨이에 대한 반도체 공급을 차단했다. 이어 바이든 대통령은 2021년 4월 12일 삼성전자, 인텔 등을 초청해 반도체 공급 확대를 위한 투자를 요 청하고, 중국에게 핵심 장비를 팔지 말라고 네덜란드를 압박했다. 이러한 전략은 트럼프 행정부의 기조를 이어받은 것으로, 반도체 공급부족 사태를 계기로 미국이 글로벌 산업경쟁에서 주도권을 확

11) 미국의 33 년 만의 전쟁, 중국의 33 년간의 전쟁. 관행중국, vol. 999. 인하대학교 중국·화교문화연구소. https://aocs.inu.ac.kr/webzine/app/view.php?wp=404

12) 트럼프 대통령은 취임사(2017. 1. 20)에서 “오늘부터 미국의 새 비전은 미국 우선주의”라고 선언하고, 외교, 국방, 통상 등 국정 전 분야에서 미국의 이익을 최우선시하는 정책을 공언하였다(박행웅, 2018, 트럼프의 미국 우선주의. 경기: 한울). 
보하기 위한 것으로 평가된다.

셋째, 외교 분야이다. 1979년 미국은 중국과 수교하면서 대만과의 외교관계를 단절했지만, 2018 년 대만 여행법을 승인하여 고위 관료의 대만 방문을 허용했다. 2020년 7월에는 중국의 홍콩 보안 법 제정에 맞서 ‘홍콩 정상화’에 관한 행정명령에 서명했다. 2020년 9월 유엔 총회에서는 “중국이 코로나바이러스 감염증 대유행의 책임을 져야 한다"라고 주장했다. 이처럼 트럼프는 양안 관계나 코로나 같은 글로벌 성격의 문제를 활용하여 국제무대에서 중국을 전방위적으로 압박함으로써 외 교적으로 고립시키려는 전략을 구사하였다. 바이든 행정부는 오바마 행정부의 실용주의적 '스마트 외교'와 트럼프 행정부의 ‘미국 우선주의'를 적절히 조합한 외교정책을 추진하고 있다. 핵심 이슈는 트럼프와 마찬가지로 중국이지만, 중국을 견제할 국제연대를 결속하는 과정에서 동맹 우선주의를 채택하였다(Bong, 2021, p. 11). 이와 같은 바이든 정부의 움직임은 미국이 국제사회에서 고립무원 에 빠지면 곤란하다는 위기감의 표출로 보인다.

정리하면, 트럼프의 안보 전략은 '미국 우선주의(America First)' 기조하에 중국을 압박하는 것이 다. 반면 바이든 대통령은 ‘동맹 우선주의(Alliance First)'를 선언하면서 '미국 우선주의'의 청산에 들어갔다. 하지만 중국에 대한 미국의 기본전략은 큰 변함이 없어 미 - 중 갈등이 지속될 전망이다.

\section{3 중국의 대미전략}

시진핑 주석은 2012년 11월 18차 당 대회에서 공산당 총서기로 추대되면서 '중국몽(中國夢)'을 국가이념으로 내세웠는데, 이는 '위대한 중화민족의 부흥'을 의미한다. 중국의 안보 관련 대미전략 은 앞서 언급한 미국의 대중전략과 동일하게 군사, 경제, 외교 분야로 구분하여 살펴보겠다.

첫째, 군사 분야에서 중국은 '적극적 방어'를 군사전략의 기반으로 하였고, 이의 실천전략으로 반 접근 및 지역거부(A2/AD: Anti-Access Area Denial)13)를 표명하였다. 반접근은 ‘중장거리 무기체 계를 이용하여 작전 영역 내부로 적의 진입을 차단하는 것'을 의미하고, 지역거부는 '단거리 무기로 작전지역 내부에서 적 작전 행동의 자유를 제한하는 것'을 의미한다. 이를 위해 태평양 섬을 연결한 2 개의 도련선(Island Chain)을 설정하였다. 중국은 쿠릴열도 오키나와 필리핀을 연하는 1도련선 에 단거리 대함탄도미사일, 구축함, 지대함 순항미사일, 전투기 등을 배치하여 미국의 군사작전을 제한하는데 작전 주안을 두고 있다. 또한, 동경 사이판 괌을 연결하는 2 도련선에서 중거리대함 탄도미사일, 항공모함, 이지스형 구축함, 폭격기 등으로 미국 항모전단의 접근을 거부하는데 작전 주안을 두고 있다(Kim, T. H., 2020, pp. 45-46). 한편, 2021년 1월 1일 중국은 ‘중화인민공화국 국방 법'을 개정했다. 중국 국무원은 이번 개정안의 특징이 “어느 한 국가가 패권주의를 행사하는 것을 저지하는 것이다"라고 소개했다.14) 이는 미국과의 강대국 경쟁에서 군사력 우위를 선점하기 위한

13) 대미전략 $\mathrm{A} 2 / \mathrm{AD}$ 는 미국이 바라본 중국의 서태평양 영역지배 전략을 부르는 명칭임.

14) 한국군사문제연구원(2021.1). 중화인민공화국 『국방법』개정과 함의. KIMA NewsLetter, 912. https://www.kima.re.kr/ 
법적 근거를 마련하고, 세계 도처에서 대두되는 중국 위협론을 불식시키려는 의도로 평가된다.

둘째, 경제 분야이다. 중국은 1980년대 도광양회(鞱光養晦), 2003년 화평굴기(和平崛起), 2004년 유소작위(有所作爲)라는 슬로건을 내걸고 미국을 빠르게 추격했다. 이때 자본주의 경제체제를 일 부 수용하여 시장을 개방하였고, 경제 성장률은 1978 년부터 30 여 년 동안 매년 $10 \%$ 대의 성과를 거 두었다. 그런데 2011년 이후 성장률이 감소하였으며, 중국은 이를 '신창타이15)'라 판단하면서 '일대 일로16)'의 해결전략을 제시했다. 이를 통해 미국을 억제하고 패권 국가의 지위로 올라서기 위한 글 로벌 파트너십을 구축할 것으로 평가된다. 중국은 2017년 10월 19차 당 대회에서 2035년까지 '사회 주의 현대화를 실현하여 경제적으로 미국을 추월하겠다고 천명했다. IMF도 중국이 현재 수준의 경제성장 속도를 유지할 경우, 2030년에서 2035년이 되면 미국 GDP 규모를 넘어선다고 예측하였 다.17) 이와 같은 중국의 경제전략은 2035년을 목표로 미국을 추월하여 '사회주의 현대화 강국 건설' 을 통한 세계의 패권국이 되겠다는 의도이다.

셋째, 외교 분야이다. 중국 외교정책의 기조는 다음과 같이 정리할 수 있다.18) (1) 흑묘백묘(黑猫 白猫): 이념보다 실리를 추구한다. (2) 도광양회(鞱光養晦): 실력을 감추고 역량을 길러라. (3) 유소 작위(有所作爲): 실력을 숨기면서도 해야 할 일은 한다. (4) 화평발전(和平發展): 주변 국가와 갈등 없이 경제성장을 추구한다. (5) 왕도적비(王道的秘): 명분을 세워 타국의 협력을 구한다. (6) 왕표패 리(王表覇裏): 겉으로는 명분을 내세우면서 실제로는 패권을 추구한다. 그런데 중국 외교의 고민은 많은 나라와 영토분쟁을 겪고 있는 점이다. 동으로는 대한민국을 비롯하여 일본, 남으로는 대만, 괌, 필리핀, 태국, 싱가포르, 파키스탄, 인도, 아프가니스탄과 대립하고, 북에서는 러시아와 마주하고 있다. 이처럼 중국과 대립하는 주변국들은 미국의 외교적 포용 대상이 될 수 있다. 미국은 중국의 움직임에 자극받은 주변국들과 연대하여 포위망을 형성하고 있다. 가령, 센카쿠 열도의 중 - 일 분 쟁에 대해 오바마 정부는 일본의 손을 들어 중국을 견제하는 등 상대의 적이 외교적 우군으로 영향 을 미치도록 관계를 형성하고 있다.

정리하면, 중국은 고속 성장한 경제력을 근간으로 미국의 패권 지위를 넘보고 있다. 이러한 현상 은 시간이 지남에 따라 군사- 외교적인 문제로 도전 범위가 확대되었다. 즉, 중국의 대미전략에 따

\section{3.html?Table=ins kima newsletter\&s=11\&mode=view\&uid=956\&page=8\&section=}

15 ) '신창타이(新常態, New Normal)'는 중국경제의 '새로운 상태’를 일컫는다. 2008년 미국발 세계금융위기에 직면하면서 고속성장이 둔화되자, 시진핑 주석이 2014년 5월 허난성 시찰 도중 언급했다(이수행, 2016, pp. 1-20. 중국 신창타이 경제의 등장과 시사점. 이슈\&진단, 233, 1-25...)http://www.dbpia.co.kr/journal/articleDetail?nodeId=NODE07060875

16) ‘일대일로(一帶一路, One belt, One road)'는 35년 간(2014 2049) 고대 실크로드를 현대판으로 다시 구축해 경제 • 무역을 확대하려는 프로젝트다. 2013년 시진핑 주석이 제안했고, 2017년 현재 100여 개 국가 및 국제기구가 참여하고 있다(Cho, J. W., 2020, pp. 281-306).

17) 한국경제TV(2020. 10. 26). '미국 추월' 미리 대비하겠다는 중국공산당...2035년까지 논의. https://www.kvina.co.kr/ newsCenter/view.asp?articleId $=$ AKR20201026070900089\&pgCode $=0303 \& p a g e=\&$

18) 김명섭, 김계동, 홍현익, 이상환, 이신화, 최진우, 전재성, 남궁곤, 윤진표, 신범식, 김태효, 마상윤, 유진석, 이근욱, 조양현, 차창훈 (2012). 현대외교정책론. 서울: 명인문화사. 
A study of the United States of America and China's new cold war conflicts and ... / Haesoo Yang 101

른 미·중의 갈등은 다방면에서 전방위적으로 진행되고 있다.

\section{4 미·중 갈등이 한국 안보에 미치는 영향}

미국의 대중전략과 중국의 대미전략에서 살펴보았듯이 미 - 중은 다양한 부문에서 상호 이해관 계를 달리하고 있다. 이때 한국 안보와 관련된 유의미한 파생 요인들이 도출되었다.

\subsection{1 군사 분야}

한국 주변에서 미 - 중의 군사적 대립은 이내 남북문제로 귀결된다. 미국은 인도-태평양 전략에 서 북한을 불량국가로 지정하였는데, 그 원인이 된 북핵 문제를 두고 해결방안에 대해 중국과 갈등 이 야기될 수 있다. 중국은 중화인민공화국 국방법에서 한 국가의 패권주의를 저지하겠다 천명하였 으며, 이로 인해 중국 가까이 주둔한 주한미군의 역할은 갈등의 불씨이다.

첫째, 북핵을 바라보는 시각이다. 북핵 문제는 미국이 한반도에서 패권을 유지하는데 큰 도전이 다. 냉전 시기(1953 1990년)에 미국은 전술핵무기로 한국에 핵우산을 제공하여 북한의 공세에 대 응하고 중국의 개입을 차단하고자 했다. 냉전 붕괴 이후 북한의 핵 개발 기간(1990 2006년)에는 당근과 채찍으로 억지를 시도하였으나, 북한의 붕괴를 우려한 중국이 거부권을 행사하여 억지 전략 에 실패했다. 이어 북한의 제1차 핵실험부터 오바마 시대(2006 2016년)에는 북한의 잇따른 핵실험 과 핵무기 고도화에도 불구하고, 경제적 봉쇄로 북한의 붕괴를 기다린다는 '전략적 인내’ 정책을 적 용했다. 트럼프 정부(2017 2021년)는 '최대 압박과 관여' 정책으로 핵 개발을 억지하였고, 북한의 제6차 핵실험 시 UN 안보리 차원의 제재에 중국과 러시아를 동참시켰다(Lee, S. U., 2019).

바이든 행정부의 북핵 문제에 대한 태도는 명확하게 드러나지 않는데, 북핵 문제를 우선 과제가 아닌 것으로 판단하는 것 같다. 또는, '전략적 인내’라는 이름으로 대응 수위가 낮았던 오바마 행정 부와 유사한 정책을 구상하는 것으로 예견된다. 반면, 중국은 북핵 문제를 평화적인 북 - 미 협상으 로 해결되어야 한다는 의도이다. 2009년 2차 핵실험으로 북핵 문제가 악화되었을 때 '조용한 역할' 에서 '대화의 주선자'로 변신하거나, 나아가 미국에 협조하여 북한을 압박하기도 했다. 2016년 4차 핵실험으로 북핵 고도화에 대한 ‘중국책임론’이 등장하자, 중국은 북핵 문제의 당사자는 미국이라 며 ‘미국책임론'으로 맞대응했다(Lee, D. R., 2019). 이렇듯 미국과 중국은 북한의 비핵화에 찬성하 고 있다. 미국은 북한의 핵보유국 지위를 절대 인정할 수 없으며, 이를 위해 어떤 통제 방법도 불사 하겠다는 생각이다. 반면, 중국은 북한의 체제를 보장하면서 '장기적 관점'으로 접근하자고 주장하 여 미·중의 갈등 요인이다.

둘째, 주한미군의 역할에 대한 논쟁이다. 주한미군은 1953년 10월 1일 델레스 미 국무장관과 변 영태 외무장관이 한미상호방위조약에 서명하면서 한반도 주둔을 위한 법적 근거가 마련되었다. 당 시 한국 정부(공보처)는 본 조약으로 "동양에 항구적인 평화를 건설하는 데 있어서 기본적인 토대 
가 마련되었다”라며 동북아시아 안전보장이 주한미군의 역할이라고 밝혔다.19) 2019년 2월 로버트 에이브럼스 주한미군사령관은 미 상원에 출석해 “주한미군 주둔은 한국의 안전을 보장하며 중국의 영향력 확대에 대한 방어막 역할을 한다”라고 밝혔다. 주한미군의 적이 중국이라는 발언은 미국과 중국이 무력 충돌 시 한국도 방관하거나 중립적인 위치에 있을 수 없다는 시각이다.

중국은 주한미군의 역할이 불편하다. 주한미군 전력은 전통적으로 한반도에 국한된 것으로 인식 되었으나, 언제든지 자신들을 향해 사용할 것에 우려하고 있다. 2006년 닝푸쿠이 주한 중국대사는 “주한미군이 제 3 국을 대상으로 행동하게 되면 우리는 관심을 돌리지 않을 수 없다”라고 말했다. 여 기서 제3국은 당연히 중국을 말하며, 주한미군의 역할에 대해 사실상 경고하고 나섰다. 주한미군의 역할론은 서해에서 충돌이 우려된다. 2018년 2020년 중국 군용기가 한국방공식별구역에 260회 진 입했다. 또한, 2013년 우성리 중국 해군사령관은 중국을 방문한 최윤희 해군참모총장에게 해군의 작전권역에 속하는 동경 124 도를 넘어오지 말라고 요구했다. 중국의 서해지역 공중 및 해상에 대한 영유권 침범은 심각한 갈등을 유발한다. 이른바 중국의 서해 내해화는 한국의 이익을 훼손하고 나 아가 미국의 국가목표에 반하기 때문이다. 주한미군이 개입하여 본연의 역할에 나서도록 영향을 미 칠 요인이다.

\section{4 .2 경제 분야}

미국의 보호주의와 중국의 사회주의 현대화 전략은 한국경제의 중국 쏠림으로 마찰 요인이다. 또한, 반도체 시장을 놓고 벌이는 미 · 중의 각축전은 글로벌 IT 업체를 보유한 한국에게 외로운 선택을 강요할 수 있다.

첫째, 미국의 보호주의는 중국과 무역 갈등을 유발하여 한국에도 악영향을 끼칠 수 있다. 미국은 초강대국이면서도 오바마 정부 이후 보호주의를 확대하는 이례적인 정책을 펴고 있다. 이때 주요 공격목표는 중국이었고, 중국 수입품에 대해 높은 관세를 부과하는 형태로 나타났다. 이에 중국은 수출통제제도와 내수 강화정책으로 대응했다. 중국은 2020년 12월 수출통제법을 발효하여 미국에 보복을 취할 수 있는 법적 근거를 마련했다. 여기에 중국의 이익을 해칠 수입상을 제재한다고 명시 하여 미국 기업을 겨냥했다. 하지만 한국 기업도 제 3 자 제재를 받을 수 있어 주의가 필요하다. 미 • 중 관세 갈등으로 한국이 반사이익을 기대하는 것은 근시안적 해법이다. 무역 갈등이 상호 보복으로 확산될 경우 대외 의존도가 높은 한국에게 악영향을 미칠 수 있기 때문이다. 특히 한국의 소재 - 부 품 수입에서 중국산이 차지하는 비중이 15 년 사이 2 배 이상 증가했다. 즉, 2004년 $14.1 \%$ 차지했던 비율이 2019년에 30.5\%를 기록했다. 이는 국내 업체들이 인건비가 싼 중국으로 생산공장을 대거 이동했기 때문이다.20)

19) 군사편찬연구소(2013, pp. 59-63). 한미동맹 60년사. 서울: 국방부.

20) 한국일보(2020.2.9.). 소재부품 수입 중국 의존도 1년새 2배, https://www.hankookilbo.com/News/Read/202002091179754449 (검색일: 2021.11.15.). 
둘째, 미국의 중국에 대한 고율의 관세 부과, 환율 조작국 지정 등 일련의 경제제재는 미국의 무 역적자 원인을 중국에서 찾고 있기 때문이다. 이의 연장선에서 반도체 시장을 둘러싼 미 - 중 갈등 역시 한반도 불안을 가중시킨다. 미국 상무부는 2020년 8월 17일 사이버보안 위험을 명분으로 중국 화웨이에 반도체 공급을 차단했고, 동시에 동맹국과 우방국에 화웨이 장비의 폐기를 요청했다. 이 에 중국은 미국의 제재에 우회할 방안을 찾지 못하고 맞대응을 회피하고 있다. 단지 내부적으로 반 도체의 연구개발, 생산에 대해 공산당에서 직접 통제하기 시작했다. 외부적으로는 일본 등지에서 중고 장비를 구매하고 있지만, 미국의 기술 없이 최첨단 반도체를 자체 해결하는 데 한계를 드러내 고 있다. 반도체를 둘러싼 미 - 중의 갈등은 단순한 무역 분쟁이기보다, 한국과 대만처럼 반도체를 생산하는 미국 동맹국의 생산 라인을 장악하기 위한 경쟁으로 전망된다. 중국에 대한 반도체 수출 비중이 3분의 2에 달하는 한국으로서는 단기적으로 매출 하락이 불가피하다. 그렇지만 미국은 한국 이 중국 중심의 경제공동체에 편입되는 것을 방관하지 않을 것이다.

\section{4 .3 외교 분야}

미국의 동맹 우선주의, 중국의 주변국 포용 정책 틈에서 해당 지역에 동시 속하는 한국은 특정 태평양 연안 협의체에 가입하도록 강요받을 수 있다. 또한, 태평양 연안의 환경문제를 놓고 중국은 일본의 원전 오염수 방류를 한국과 동일하게 반대한다. 반면, 미국은 전통적 우방 일본의 오염수 처리 방법을 지지하여 충돌이 예상된다.

첫째, 태평양 연안의 공동관심에서 오는 갈등이 한국 안보에 영향을 미친다. 2019년 11월 방콕 아세안+3 정상회의에서 '역내포괄적경제동반자협정(RCEP)'이 통과되었다. 회의를 주도한 중국은 환호했고, 미국은 곧바로 중국을 비난했다. $\mathrm{RCEP}$ 는 한국 - 중국 - 일본 - 호주를 포함한 아세안 10 개국 등 총 16 개국이 참여하는 아시아태평양지역 다자 자유무역협정(FTA)이다. 반면, 미국이 주도 하여 태평양 연안을 하나의 자유무역지대로 묶으려던 ‘환태평양경제동반자협정(TPP)'은 트럼프가 탈퇴하면서 폐기되었다. 이어 2020년 10월 피터슨경제연구소(PIIE)가 바이든 행정부에 외교정책을 권고했다.21) 핵심은 세계 국가들(한국, 일본, 유럽, 캐나다 등)과 협력하여 중국에 공동 대응해야 한 다는 내용이다. 태평양 연안은 미국과 중국의 공동관심 지역이다. 한국은 지정학적으로 양국이 주 도하는 협의체와 밀접한 관계를 맺을 수밖에 없다. 그렇다고 특정 협의체에 선택적으로 가입할 경 우, 자칫 소외된 국가로부터 제재가 우려된다. 군사 분야는 미국, 경제 분야는 중국과 협의한다는 단순 논리는 이제 최선의 방책이 아니다.

둘째, 일본 원전 오염수에 대한 외교적 해법이다. 일본 정부가 2021년 4월 13일 후쿠시마 발전소 의 방사성 오염수를 해양 방류하겠다고 발표했다. 이에 대해 한국을 포함한 주변국들은 강하게 반 대했다. 하지만 미 국무부 대변인은 “국제안전기준에 따른 것”이라는 의견을 표명하면서 오염수 방

21) 한국무역협회. (종합) 바이든 행정부 위한 권고 사항(02월 17일). https://www.kita.net/search/totalSearch.do(검색일: 2021년 5월 19일). 
류를 지지했다. 중국 매체들은 미국에 대해 ‘공범’이라며 비난했다.22) 한국, 중국 등 태평양 연안 국 가들은 일본의 오염수 방류 결정을 심각하게 바라보고 있다. 일본이 해양을 오염한다며 일본산 농 림수산물의 수입 규제 등 다양한 대응 방안을 거론하고 있다. 이때 미국이 전통적 우방 한국과 일 본 중 일본의 손을 들어준 것은 환경문제를 넘어 또 다른 역학관계에서 분석이 필요하다. 즉, 미국 이 패권에 도전하는 중국과 대응할 때 한국이라는 카드는 우선순위가 뒤로 밀릴 수 있다. 결국, 중 국과 한국, 미국과 일본으로 안보 그룹이 형성된 것은 한국 외교에 심대한 위협이 된다.

미 - 중 경쟁으로 파생된 한국 안보 현안을 안보 영역별로 살펴보았다. 이때 한국의 지정학적 딜 레마와 이로 인한 한국의 안보 현안은 총 6 건이 도출되었다. 한국 안보의 현안별로 미 - 중 시각 차 이를 위의 Table 1에 재정리했다.

$<$ Table 1> South Korea's security issues derived from US-China competition

\begin{tabular}{|c|c|c|}
\hline $\begin{array}{l}\text { Security } \\
\text { area }\end{array}$ & Security issues & Mutual conflict factors \\
\hline \multirow{2}{*}{$\begin{array}{l}\text { Military } \\
\text { field }\end{array}$} & $\begin{array}{l}\text { A solution to the North } \\
\text { Korean nuclear issue }\end{array}$ & $\begin{array}{l}\text { - US : Forced to give up nuclear weapons through pressure } \\
\text { policy } \\
\text { - China : Force denuclearization, but guarantee the regime }\end{array}$ \\
\hline & USFK's role & $\begin{array}{l}\text { - US : Allied defense purpose } \\
\text { - China : Threats to East Asian and Chinese Security }\end{array}$ \\
\hline \multirow{2}{*}{$\begin{array}{l}\text { Economic } \\
\text { field }\end{array}$} & $\begin{array}{l}\text { Friction due to } \\
\text { protectionism }\end{array}$ & $\begin{array}{l}\text { - US : Imposing high tariffs to protect the domestic economy } \\
\text { - China : Promotion of export control system and domestic } \\
\text { demand reinforcement policy }\end{array}$ \\
\hline & $\begin{array}{l}\text { The battle for } \\
\text { semiconductor market }\end{array}$ & $\begin{array}{l}\text { - US : China's high-tech pressures with semiconductor } \\
\text { control } \\
\text { - China : Refrain from responding, temporary prescription } \\
\text { with used equipment }\end{array}$ \\
\hline \multirow{2}{*}{$\begin{array}{l}\text { Diplomatic } \\
\text { field }\end{array}$} & $\begin{array}{l}\text { Formation of Pacific } \\
\text { Coast Council }\end{array}$ & $\begin{array}{l}\text { - US : Withdrawal from TPP, request for reunification of } \\
\text { traditional allies } \\
\text { - China : RCEP led, rapidly expanding power }\end{array}$ \\
\hline & $\begin{array}{l}\text { Discharge of } \\
\text { contaminated water from } \\
\text { nuclear power plants in } \\
\text { Japan }\end{array}$ & $\begin{array}{l}\text { - US : support the discharge of contaminated water } \\
\text { - China : The U.S. is an 'accomplice' in supporting the } \\
\text { discharge of contaminated water }\end{array}$ \\
\hline
\end{tabular}

22) 주간시사매거진(2020.4.14.), https://post.naver.com/viewer/postView.nhn?volumeNo $=31235820 \&$ memberNo $=31709319 \&$ vType=VERTICAL(검색일: 2021.5.20.). 


\section{IV. 한국 안보의 생존전략}

앞에서 미국과 중국의 안보 관련 상호전략에 대해 살펴보았고, 이로부터 파생되는 한국의 안보 현안을 도출하였다. 본 장에서는 안보 현안별로 한국이 선택할 최적의 생존전략은 무엇인지 분석할 것이다.

\section{1 군사 분야 생존전략}

한국 안보 현안에서 군사 분야의 미 - 중 주요 갈등 요인은 두 가지로 분석되었다. 즉, 북핵 문제 해결방안과 주한미군의 역할에 대해 양국이 시각 차이를 보였다.

첫째, 북핵 문제 해결방안에 대한 양국의 대립이다. 미국은 북한에 최대 압박을 가하여 핵을 포 기하도록 강요하겠다는 의도이다. 반면, 중국은 북한의 비핵화를 원칙적으로 동의하되, 체제를 보 장하기 위해 장기적으로 접근하자는 전략이다. 한국이 취할 수 있는 최선의 생존전략은 현재 상태 에서 북한이 핵 개발을 중단하고, 주한미군은 계속 주둔하는 것이다. 이를 위해 북한이 취득한 핵기 술을 인근 국가에 전파하지 않도록(비확산) 미·중의 협상을 중재하되, 북한에 대한 당근으로 관련 국인 한·미·일·중·러의 경제지원을 제안한다.

한국의 협상 대리인인 미국이 북핵 문제에 대해 선택할 방안은 크게 4 가지를 구상할 수 있다. 즉, (1) 핵무기 은닉장소 폭격 : 북한의 보복을 우려한 한국 정부의 반대로 무산되었다. (2) 전략적 인내 (방관) : 북한이 알아서 포기하도록 계속 인내하다 북한이 핵보유국 지위를 획득할 경우, 핵 보유 의지가 있는 한국, 일본, 대만을 통제할 명분이 사라진다. (3) 경제제재 : 단기간에 효과가 나타나지 않고, 장기적 측면에서도 정권이 붕괴하지 않고 있다. (4) 평화협정 체결 : 주한미군의 주둔 필요성 이 저하되어 중국에 대한 결정적 견제 수단을 상실한다. 여기서 (1) 핵무기 은닉장소 폭격은 한국에 서 수용하기 불가능하고, (2) 전략적 인내와 (3) 경제제재는 미국이 시도하였으나 효과가 미미하였 다. 따라서 제안사항은 (4) 평화협정 체결의 변형된 방법이다.

둘째, 주한미군의 역할로 인한 양국의 갈등이다. 미국은 동맹국인 한국을 방호하기 위해 주한미 군이 주둔하고 있다는 입장이다. 한국은 책임 국방을 실현하기 위해 굳건한 한미동맹을 기반으로 한다면서 주한미군의 필요성을 절대적으로 인식하고 있다.23) 반면, 중국은 주한미군이 동아시아 및 중국 안보를 심각하게 위협한다고 인식한다. 주한미군과 중국군이 가장 첨예하게 대립하는 지역은 서해이다. 문제는 미 - 중의 갈등을 한국이 직접 조정하기 쉽지 않다는 점이다. 따라서 차선책으로 미· 중이 원만하게 협상하도록 중재 역할을 하되, 이때 논의 과제는 서해지역 평화이용법(가칭)의 제정을 생존전략으로 제안한다. 여기에 미·중이 군사적으로 충돌할 수 있는 한·중 관련 과제를 우선 협상 목록에 상정하는 것이다. 이때 군용기 및 민항기의 운항, 서해5도의 평화적 관리, 어로활

23) 정책기획관실 기본정책과(2020, p. 169). 2020 국방백서. 서울: 국방부. 
동 안전대책, 대륙붕 이용 등에 관한 내용이 포함될 수 있다.

\section{2 경제 분야 생존전략}

한국 안보 현안에서 경제 분야의 미 - 중 주요 갈등 요인은 두 가지로 분석되었다. 즉, 양국은 보 호주의로 상호제재를 가하여 마찰을 빚고 있으며, 반도체 쟁탈전으로 한국의 입장이 난감해질 수 있다.

첫째, 양국은 보호주의하에 상호 관세 제재를 가하여 갈등을 빚고 있다. 이때 갈등의 양상은 미 국이 먼저 공세를 취하면, 중국도 수출통제제도와 내수 강화정책으로 정교하게 맞대응하고 있다. 따라서 한국 무역 시장의 다변화를 제안한다. 미국이 중국 제품에 대한 관세를 인상할 경우, 약간의 간접손실은 예상되더라도 판로를 조정해야 할 것이다. 이때 중국을 대신할 내수시장은 인구가 많은 인도나 ASEAN 국가, 나아가 미국 본토나 한국을 고려할 수 있다. 다행히 바이든 정부에서는 트럼 프 정부와 달리 관세 마찰이 줄어들 것으로 예상되나,24)유사한 무역 갈등은 지속될 것이므로 주의 가 필요하다. 중국은 내수 강화정책을 통하여 생산성 유발효과가 큰 신산업에 투자하고 있다. 이에 따라 한국은 중국의 내수 경제성장으로 반사이익을 보기 위해 중국에 대한 수출구조를 최종재 중 심으로 전환해야 한다. 특히 화장품 등 신원료에 대한 관리 규정이 완화되어 한국 화장품의 수출 허가범위가 넓어질 전망이다. 단, 화장품 안전이나 허가 규정이 더욱 엄격해져 자칫 강력한 처벌을 받을 수도 있다.25)

둘째, 미·중은 반도체 시장을 놓고 쟁탈전을 벌이고 있다. IT 강국을 자처하던 한국 기업들이 갈등의 정면에 서 있다. 2021년 4월 12 일 바이든 대통령이 반도체 칩 부족 사태의 해법을 모색한다 는 명분으로 대만 TSMC, 삼성전자 등 19 개 글로벌 기업을 초대했다. 초대한 명분과 달리 중국의 반도체 굴기를 견제하겠다는 의도일 것이다. 따라서 반도체 관련 생존전략으로 낸드플래시 분야에 파격적인 투자를 제안한다. 현재 반도체 분야에서 $\mathrm{D}$ 램 시장은 국내 기업들의 경쟁력이 우위를 점 하고 있다. TSMC 분야는 대만의 진입장벽이 높으므로 성공을 보장하기 힘들다. 필요하다면, 인수 합병 같은 공격적인 전략을 병행할 수 있으나, 이는 회사의 자본 여건에 따라 달라질 수 있으므로 투자자의 선택에 달려있다. 하버드대 윌리 시 교수는 반도체 판 왕좌의 게임에서 생존의 비결은 투 자, 즉 돈이 성패를 가를 것으로 예측했다.26) 기술집약 산업에서 2 등은 영원한 2 등이기 때문이다. 이때 투자의 방향에 대해 반도체 업체 전문가들은 미국 전략에 협력해야 한다고 판단하고 있다. 그

24) 한국무역협회(2021). (종합) 바이든 행정부 위한 권고 사항(02월 17일). https://www.kita.net/search/totalSearch.do(검색일: 2021년 5월 19일)(2021).

25 ) 한국무역협회 통상지원센터(2020). 중국 수출통제법의 주요내용과 시사점. 산업부통상교섭본부(11월 11일). https://blog.naver.com/tongsangnews/222141529839(검색일: 2021년 8월 19일).

26) 이데일리(2021.8.9). [줌인] 삼성vs인텔 반도체 패권전쟁..."성패는 투자에 달렸다", https://www.edaily.co.kr/news/ read?newsId=01167686629145680\&mediaCodeNo=257\&OutLnkChk=Y(검색일: 2021.8.19.). 
A study of the United States of America and China's new cold war conflicts and ... / Haesoo Yang 107

렇지 않으면 미국 정부가 생산품을 팔지 못하게 하는 상황에 직면할 수 있다는 지적이다.27)

\section{3 외교 분야 생존전략}

한국 안보 현안에서 외교 분야의 미 - 중 주요 갈등 요인은 두 가지로 분석되었다. 즉, 태평양 연 안에 대한 공동관심과 일본 오염수 방류 결정에 대해 양국이 시각 차이를 보였다.

첫째, 태평양 연안의 공동관심에 대한 양국의 대립이다. 앞에서 살펴보았듯이, 미국은 TPP 탈퇴 후 전통적 우방이 재결집하자는 의도이다. 반면, 중국은 $\mathrm{RCEP}$ 를 주도하여 세력을 확대하겠다는 전 략이다. 미국과 중국은 인도-태평양 연안 국가들을 두고 치열한 외교 경쟁을 벌이고 있다. 중국의 위안화 공세에 캄보디아와 라오스가 중국으로 기울었고, 호주와 뉴질랜드는 중국 자금이 정계로 유 입되면서 미 - 중 경쟁의 진원지로 탈바꿈했다는 분석이다.28) 따라서 태평양 연안 협의체에 관한 생존전략은 조기에 협의체 가입 의사를 밝히지 말고 기회를 기다리다, 제 3 의 전략적 동반자 구축을 제안한다. 미국과 중국은 경제적 필요로 밀접한 관계를 맺었다가, 각자 태평양 지역 협력체를 만들 어 이합집산했다. 한국 외교가 그 중심에 있는데, 그렇다고 섣불리 어느 한쪽을 선택하는 것은 위험 하므로 주변국의 반응을 살피며 시간을 끄는 방안을 제안한다.

이와 병행하여, 한국은 제 3 의 전략적 동반자를 마련해야 한다. 전통적으로 한국은 미국과 일본을 제 1,2 의 전략적 동반자로 인식했다. 그러나 세계 많은 국가가 '자국우선주의' 외교전을 전개하는 상황에서 특정 국가에 치중한 외교관계는 유사시 고립무원에 빠질 수 있다. 천연자원을 고려한다면 몽골 - 호주, 값싼 노동력이나 수출시장을 고려한다면 베트남 - 인도, 안정된 석유공급을 고려한다 면 사우디아라비아· UAE - 인도네시아를 모색할 수 있다.

둘째, 일본의 원전 오염수 방류 결정으로 인한 대립이다. 이에 대해 미국은 일본의 오염수 방류 를 사실상 지지하는 반면, 중국은 오염수 방류를 지지한 미국을 ‘공범’이라고 비판하여 한국처럼 반 대한다. 일본의 원전 오염수 방류를 반대하는 나라는 한국을 비롯하여 중국, 대만, 북한 등이고, 미 국, 라파엘 마리아노 그로시 IAEA 사무총장 등이 찬성하고 있다. 이에 한국과 입장을 같이하는 나 라와 공동으로 대응하자고 생존전략을 제안한다. 예를 들면, 오염으로 주변국이 입을 환경피해를 공동으로 연구하고 그 결과를 각국에 홍보하는 것이다. 또한, 일본산 수산물에 대한 검역기준을 관 련국들과 공동으로 관리하는 방안도 있다. 역사적으로 미국이 한일 대립 문제를 일본에 유리하도록 체결한 사안 중에 1951년 9월의 샌프란시스코강화조약이 있다. 이때 한국은 일본으로부터 가장 많 은 피해를 받고도 보상을 받지 못했다. 미국이 배상 청구권을 포기하고, 전쟁의 책임 문제를 강화조 약에 명기되지 않은 것이 이유이다.29)

27) the bell(2021.5.26). '반도체 원조' 미국서 다진 메모리 - 파운드리 성장기반. http://www.thebell.co.kr/free/content/ ArticleView.asp?key=202105141041388160102556\&svccode=00\&page=1\&sort-thebell_check_time(검색일: 2021.8.19.).

28) 김택환(2019, p. 187). 세계 경제패권전쟁과 한반도의 미래. 경기: 김영사. 
또한, 한일군사정보보호협정(GSOMIA)30)은 2016년 한국과 일본이 군사정보를 직접 공유하기 위해 맺은 군사협정이다. 협정 논의 당시 미국은 한국에 대해 협정 체결을 압박한 바 있다. 미국으 로선 동북아에서 한 - 미·일 안보협력을 더욱 강화하고, 중국 견제까지 가능한 수단이기 때문이 다.31) 이렇듯 한일의 대립상황에서 미국은 일본의 주장을 전략적으로 선택했던 사실을 염두에 두 어야 한다.

\section{V. 결론 및 논의}

냉전체제에서 대립은 당사국 자체 문제로 종결되었다. 그런데 미 - 중 신냉전에 따른 양국의 갈 등은 과거의 냉전과 달리 주변국에게 한 진영을 선택하도록 요구할 수 있다. 미국은 한국에게 전통 적인 우방으로 한국전쟁을 통하여 혈맹관계를 맺은 이후 돈독한 관계를 유지하고 있다. 지금 시간 에도 한국은 미국과 함께 북한의 도발로부터 대비태세를 공유하고 있으며(Yang, H. S, 2018), 미국 에 대한 안보 의존도가 높다. 이와 병행하여 한국은 지리적 영향으로 중국에 대한 경제 의존도가 높다. 이러한 상황에서 한국이 미국, 또는 중국으로부터 어느 한 진영을 선택하라고 요구받는다면 정책 결정에 큰 딜레마가 된다.

본 연구는 미국과 중국의 신냉전이 도래한 상황에서 한국 안보의 유연한 생존 방안을 분석하는 것이다. 이를 위해 우선 미국 및 중국이 상대국에 적용하는 각각의 전략 속에서 한국에 영향을 미 치는 안보 현안을 살펴보았다. 미· 중 경쟁으로 인해 파생되는 한국의 지정학적 딜레마를 연구 결 과, 그로 인한 한국의 안보 현안 6 건이 도출되었다. 여기에는 북핵 문제 해결방안, 주한미군의 역할, 보호주의로 인한 마찰, 반도체 시장 쟁탈전, 태평양 연안 협의체 구성, 일본 원전 오염수 방류가 포 함된다.

다음으로 한국의 안보 현안별로 미 - 중 갈등 요인에 대한 생존전략을 고찰하였다. 이때 한국에 위협이 되는 상황을 군사 분야, 경제 분야, 외교 분야로 구분하여 안보 관련 분야별 정책결정자들에 게 방향성을 제시하였다. 즉, 본 연구는 정책적 활용성에 학문적 가치를 두었다.

안보 분야별 생존전략은 다음과 같다. 첫째, 군사 분야는 북한이 취득한 핵기술을 인근 국가에 전파하지 않도록(비확산) 미 - 중과 협상하고, 미·중의 군사적 충돌을 방지하기 위해 서해지역 평 화이용법(가칭)을 제정한다. 둘째, 경제 분야는 한국의 무역 시장을 다변화하고 중국의 내수 강화정

29) 송송이(2019). 샌프란시스코 강화 조약. 정세와 노동, 154. 노동사회과학연구소. http://www.dbpia.co.kr/ journal/articleDetail?nodeld=NODE09216706

30) 군사정보보호협정, General Security of Military Information Agreement(GSOMIA; 지소미아).

31) YTN(2019.7.19). [뉴스TMI] 한일군사정보보호협정, GSOMIA는 왜 미국을 긴장시키는가?. https:/www.ytn. co.kr/_ln/0104_201907191607417018 
책에 부응하여 최종재 중심으로 수출구조를 전환하며, 반도체에서 낸드플래시 분야에 파격적으로 투자한다. 셋째, 외교 분야는 태평양 연안 협의체 가입을 가능한 미루다 제3의 전략적 동반자를 마 련하고, 일본의 원전 오염수 방류는 중국을 비롯하여 한국과 입장을 같이하는 나라와 환경피해나 검역기준을 공동으로 관리한다.

앞에서 언급한 연구의 성과에도 불구하고 어느 정도 한계가 있었는데, 이는 국제관계의 불확실 성에서 오는 문제점이다. 글로벌 시대에 특정 국가 정치지도자의 교체, 국민 성향이나 여론 등의 갑작스러운 변화는 다른 국가와의 국제관계에도 밀접한 영향을 끼친다. 이와 같은 예상치 못한 정 치적 환경의 변화는 본 연구에서 분석요인으로 설정하기에 한계가 있으며, 제시한 정책적 제안을 적용하는 과정에서 신뢰도를 저하시킨다. 따라서 본 연구 결과를 정책에 적용할 경우, 정치적 상황 변화를 면밀하게 검토하면서 융통성 있게 추진한다면 활용성을 한층 더 높일 것이다.

미국과 중국은 각종 현안에서 첨예하게 대립하자, 양국 모두 확고한 우방국이 절실해졌다. 이제 '군사협력은 미국, 경제협력은 중국'이라는 단순 논리는 성립되지 않는다. 미·중이 서로 협력할 수 도 있으므로 섣부른 줄서기는 금물이며, 주변 동맹국들의 반응을 살피다 한 박자 쉬고 결정하는 것 이 현실적일 수도 있다.

\section{Acknowledgements}

We would like to thank Editage (www.editage.co.kr) for English language editing.

\section{Declaration of Conflicting Interests}

The author(s) declared no potential conflicts of interest with respect to the research, authorship, and/or publication of this article. 


\section{Reference}

Ban, K. J. (2021). Cold War vs. New Cold War: Analyzing Inherent Dynamics of the U.S.-China Hegemonic Competition. National Security and Strategy, 21(1), 1-53. https://www.kci .go.kr/kciportal/ci/sereArticleSearch/ciSereArtiView.kci?sereArticleSearchBean.artild=AR T002698556

Bong, Y. S. (2021, May). 100 day of Biden Administration and Korean Peninsula Security. Korea Institute for Military Affairs, 39, 3-11. https://www.kima.re.kr/3.html?html=3-93.html\&s=9\&uid=381

Cho, J. W. (2020). Industrial Cooperation Between China's Belt and Road Initiative and Kazakhstan's Nurly Zhol. The Korean Association of Slavic-Eurasian Studies, 35(4), 281-306. https://www.kci.go.kr/kciportal/ci/sereArticleSearch/ciSereArtiView.kci? sereArticleSearchBean.artiId=ART002663622

Gingrich, N. (2019). Trump us. China: Facing America's Greatest Threat. New York: Center Street.

Kim, B. J. (2018). The Foreign Policy of the Reagan Administration and the End of the Cold War. The Korean Journal of American History, 48, 249-280. https://doi.org/10.37732/ KJAH.2018.48.249

Kim, H. K. (2014). The Rise of China and the World Order in the 21st century: the U.S.-China Relation in the view of Power Transition Theory. Journal of Golobal Politics, 7(1), 137-166. https://www.kci.go.kr/kciportal/ci/sereArticleSearch/ciSereArtiView.kci? sereArticleSearchBean.artiId=ART002403193

Kim, T. H. (2020). Trump's US Military Strategy against China: Competitive Strategy and Cost-imposing. National Strategy, 26(2), 35-63. https:/www.kci.go.kr/kciportal/ci/ sereArticleSearch/ciSereArtiView.kci?sereArticleSearchBean.artild=ART002588605

Lee, D. R. (2019). China's Strategy and Role on the Korean Peninsula's Denuclearization and Peace Process. Korea and World Politics, 35(1), 157-192. https://doi.org/10.17331/ kwp.2019.35.1.006

Lee, S. H. (2020). International Politics of Post COVID-19 Era: Deglobalization, Digitalization and Neo-Cold War Order. THE JOURNAL OF POLITICAL SCIENCE \& COMMUNICATION, 23(3), 151-166. https://doi.org/10.15617/psc.2020.10.31.3.151

Lee, S. U. (2019). US Deterrence Strategy and North Korean Nuclear Issue. Journal of Ethics, 
1(126), 281-306. https://doi.org/10.15801/je.1.126.201909.281

Organski, A.F.K. (1968). World Politics. New York City: Knopf. https://scholar.google. com/scholar_lookup?title=World\%20Politics\&publication_year=1968\&author=Organski\%2C AFK

Yang, H. S. (2018). A Study on the Transformation to the Provocation Intention of North Korea According to the Behavior of Provocation. Review of Korean Military Studies, 7(1), 3-37. https://doi.org/10.34166/rokms.2018.7.1.3 
IDAP 광운대학교 방위사업연굿소

2021, Vol. 4, No. 3, 91-112.

https://doi.org/10.37944/jams.v4i3.123

\title{
미·중 신냉전에 따른 한국 안보의 유연한 생존전략에 관한 연구
}

\author{
양해수**
}

\section{국문초록}

중국이 경제력을 바탕으로 미국의 패권에 도전하고 있다. 이른바 신냉전이다. 미·중의 신냉전으로 인한 양국의 갈등은 한국에게 한 진영을 선택하도록 요구할 수 있다. 한국은 군사적으로 미국에, 경제 적으로 중국에 의존도가 높다. 이러한 상황에서 선택적 지지를 요구받는다면 정책 결정에 딜레마가 된다. 이에 따라 중국에 대한 미국의 전략과 미국에 대한 중국의 전략을 연구하였다. 이때 미· 중 경쟁 으로 인해 파생되는 한국의 지정학적 딜레마와 그로 인한 한국의 안보 현안 6건을 확인할 수 있었다. 여기에는 북핵 문제 해결방안, 주한미군의 역할, 보호주의로 인한 마찰, 반도체 시장 쟁탈전, 태평양 연안 협의체 구성, 일본 원전 오염수 방류가 해당한다. 안보 현안별로 한국이 선택할 수 있는 유연한 생존전략에 대해 살펴보았다. 이때 군사 분야, 경제 분야, 외교 분야로 생존전략을 구분하여 제시함으 로써 정책적 활용성을 기대했다.

주제어 : 미·중 갈등, 신냉전, 보호주의, 생존전략, 태평양 협의체

* 본 연구는 2021년도 서경대학교 교내연구비 지원에 의하여 이루어졌음.

** (제1저자) 서경대학교 군사학과 교수, didgotn@hanmail.net, https://orcid.org/0000-0003-4626-0302 